\title{
Occurrence of Lysiphlebus testaceipes (Cresson, 1880) (Hymenoptera: Braconidae: Aphidiinae) parasitizing Aphis forbesi Weed, 1889 (Hemiptera: Aphididae) in the strawberries crop in the Metropolitan Region of Curitiba, Parana, Brazil
}

\author{
Araujo, ES. ${ }^{a *}$, Zawadneak, MAC. ${ }^{b}$,Tavares, MT. ${ }^{c}$, Benatto, A. ${ }^{b}$ and Mógor ÁF. ${ }^{d}$ \\ aPrograma de Pós-graduação em Agronomia - Produção vegetal, Departamento de Fitotecnia e Fitosanitarismo, \\ Universidade Federal do Paraná - UFPR, Rua dos funcionários, 1540, CEP 80035-050, Curitiba, PR, Brazil \\ 'Departamento de Patologia Básica, Universidade Federal do Paraná - UFPR, \\ Jardim das Américas, CEP 81531990, Curitiba, PR, Brazil \\ 'Departamento de Ciências Biológicas, Universidade Federal do Espírito Santo - UFES, \\ Av. Marechal Campos, 1468, CEP 29.043-900, Vítória, ES, Brazil \\ dDepartamento de Fitotecnia e Fitossanitarismo, Universidade Federal do Paraná - UFPR, \\ Rua dos funcionários, 1540, CEP 80035-050, Curitiba, PR, Brazil \\ *e-mail: emiagro@yahoo.com.br
}

Received October 10, 2011 - Accepted June 6, 2012 - Distributed February 28, 2013

Aphids (Hemiptera: Aphididae) are considered key pests of strawberry plants (Botton et al. 2010; Cédola and Greco, 2010). Among the aphid species related to this culture, Aphis forbesi Weed, 1889, a monophagous species known as root aphid (Botton et al., 2010) stands out. This species develops on stems along the base of plants, often associated with ants. These ants build nests around the aphid colony, which makes chemical control and fruit harvest difficult (Salles, 2005; Botton et al., 2010).

In August 2010, eight specimens of A. forbesi parasitised on a strawberry plantation grown in Pinhais, $\mathrm{PR}\left(25^{\circ} 25^{\prime} \mathrm{S}\right.$ and $49^{\circ} 08^{\prime} \mathrm{W}, 930 \mathrm{asl}$, Cfb climate) were collected. The parasitoids specimens were identified by Marcelo Teixeira Tavares from the Biological Sciences Department of UFES, Vitoria, Espirito Santo as Lysiphlebus testaceipes (Cression, 1880) (Hymenoptera: Braconidae: Aphidiinae).

It is a solitary endoparasitoid of aphids distributed over five continents (Rodrigues, 2003). L. testaceipes is one of the most common species of Aphidiinae in South America (Starý et al., 2007). Zanini et al. (2006) reported the occurrence of L. testaceipes parasitising Metopolophium dirhodum aphids (Walker, 1849), Rhopalosiphum maidis (Fitch, 1856), Rhopalosiphum padi (Linné, 1758) and Sitobion avenae (Fabricius, 1775) in the wheat culture in Medianeira, Parana, Brazil. Starý et al. (2007) also reported this species and add 19 aphids species as hosts in Brazil. The use of L. testaceipes as a biological control agent for Aphis gossypii was considered promising by Rodrigues et al. (2001).

The aphid $A$. forbesi was recorded as a host of L. testaceipes (Cresson, 1880) as well as Adialytus fuscicornis (Ashmead, 1891), Lysiphlebus fabarum (Marshall, 1896) and Trioxys gahanI Smith 1944 (Yu, 2010). This is the first report of the occurrence of Lysiphlebus testaceipes (Cresson), parasitising Aphis forbesi in the strawberry crop in Paraná. This record contributes to a better understanding of the entomofauna associated with the strawberry crop and can support future work on aphids management.

Acknowledgements - We thank $C N P q$ (Conselho Nacional do Desenvolvimento Científico e Tecnológico) and the Ministério da Agricultura, Pecuária e Abastecimento (MAPA) for financial support, and Project Taxon line/Universidade Federal do Paraná.

\section{References}

BOTTON, M., BERNARDI, D., NAVA, DE., CUNHA, US. and GARCIA, MS., 2010. Manejo de pragas na cultura do morangueiro. In Resumo do $5^{\circ}$ Simpósio Nacional do Morango e do $4^{\circ}$ Encontro sobre Pequenas Frutas e Frutas Nativas do Mercosul, 2010. Pelotas. p. 23-29.

CÉDOLA ,C. and GRECO, N., 2010. Presence of the aphid, Chaetosiphon fragaefolii, on strawberry in Argentina. Journal of Insect Science, vol. 10, no. 9, p. 9. http://dx.doi. org/10.1673/031.010.0901

RODRIGUES, SMM., 2003. Avaliação de Lysiphlebus testaceipes (Cresson, 1880) (Hym.: Aphidiidae) como agente de controle biológico de pulgões em cultivos protegidos. Lavras: Universidade Federal de Lavras. 106 p. Tese de Doutorado em Entomologia.

RODRIGUES, SMM., BUENO, VHP. and BUENO-FILHO, JSS., 2001. Desenvolvimento e Avaliação do Sistema de Criação Aberta no Controle de Aphis gossypii Glover (Hem.: Aphididae) por Lysiphlebus testaceipes (Cresson) (Hym.: Aphidiidae) em Casa-de-Vegetação. Neotropical Entomology, vol. 30, no. 3, p. 433-436. http://dx.doi.org/10.1590/S1519-566X2001000300016

SALLES, LA., 2005. Pragas do morangueiro. Embrapa Clima Temperado. Sistemas de Produção, n. 5. Sistemas de produção de morango. versão Eletrônica. Available from: <http:// sistemasdeproducao.cnptia.embrapa.br/FontesHTML/Morango/ SistemaProducaoMorango/cap07.htm>. Access in: 03 Apr. 2010.

STARÝ, P., SAMPAIO, MV. and BUENO, VHP., 2007. Aphid parasitoids (Hymenoptera, Braconidae, Aphidiinae) and their 
associations related to biological control in Brazil. Revista Brasileira de Entomologia, vol. 51, no. 1, p. 107-118. http:// dx.doi.org/10.1590/S0085-56262007000100018

YU, DSK. Home of Ichneumonidae. 2010. Available from: <http:// www.taxapad.com/local.php?showpage $=$ taxonomy $>$. Access in: 03 June 2011.
ZANINI, A., PRESTES, TMV., DALMOLIN, MF., ALVES, LFA. and MENEZES-JUNIOR, AO., 2006. Ocorrência de Lysiphlebus testaceipes (Cresson) (Hymenoptera: Aphidiidae) parasitando pulgões (Hemiptera: Aphididae), em trigo em Medianeira, PR. Neotropical Entomology, vol. 35, no. 2, p. 275-276. http://dx.doi. org/10.1590/S1519-566X2006000200020 